\title{
Idea Evaluation in Innovation Management for the New Normal in Banking: A Case Study in Vakıfbank
}

\author{
Şenay Demirel \\ Süha Erdem Yabaş ** \\ Çağlar Üçler ${ }^{* * *}$ \\ Sait Şener ${ }^{* * *}$ \\ Metin Recep Zafer ${ }^{* * * *}$
}

\begin{abstract}
Banking environment, traditional with an established physically collocated work culture, has been disrupted by the COVID-19 pandemic. It triggered the evolution of innovation management processes to handle the issues related to spatial spread, fuzziness and collective information development during idea evaluation. In this paper, Vakıfbank Innovation Management System (V-IMS) was exemplified utilizing ICT for virtual collaboration, MCDM (Multi Criteria Decision Making) methods within stage-gates, transforming knowledge and exploiting collaboration at the fuzzy front end. There, physically collocated work culture was transformed into delocated collaboration with an agile approach utilizing lean information flow, which emphasizes the people exchanging tacit into explicit knowledge on the move rather than long documentations. Moreover, the culture of innovation has been fostered, innovation management metrics were improved significantly and both the number of sessions and ideas presented in the sessions were found to be increased. It was observed that the satisfaction level and innovation commitment of the employees were increased with the new system as well.
\end{abstract}

Keywords: Banking, Innovation management, Ideation, Idea evaluation, New normal, Virtual collaboration, Fuzzy front end.

JEL Classification: M10, O32

\section{Öz - Bankacılıkta Yeni Normal için İnovasyon Yönetimi Kapsamında Fikir Değerlendirmesi : Vakıfbank'ta Bir Örnek Olay}

COVID-19 salgını, fiziksel olarak yerleşik bir çalışma kültürüne sahip geleneksel bankacılık ortamını etkilemiştir. Salgın nedeni ile inovasyon yönetimi süreçlerinin gelişmesi ve mekansal yayılma, belirsizlik ve toplu bilgi geliştirme gibi sorunları ele alması gerekmiştir. Bu çalışmada, VakıfBank İnovasyon Yönetim Sistemi (V-IMS) üzerinde, sanal işbirliği için BT kullanımı, karar noktalarında MCDM yöntemleri kullanımı, zımni açık bilgi ve bulanık ön uçta uzak işbirliği dönüşümü örneklendirilmiştir. Bu sistemde, fiziksel olarak yan yana yerleştirilmiş çalışma kültürü, insanların uzun belgelerden ziyade hareket halindeyken zımni bilgi alışverişini vurgulayan yalın bilgi akışını kullanan çevik bir yaklaşımla ayrık işbirliğine dönüştürülmüştür. Ayrıca inovasyon kültürü teşvik edilmiş, inovasyon yönetimi ölçütleri önemli ölçüde iyileştirilmiş ve hem oturum sayısı hem de oturumlarda sunulan fikirlerin arttığı görülmüştür. Ayrıca yeni sistemle birlikte çalışanların memnuniyet düzeylerinin ve yenilik bağlııklarının arttığı da gözlemlenmiştir.

Anahtar Kelimeler: Bankacılık, İnovasyon yönetimi, Fikir geliştirme, Fikir değerlendirme, Yeni normal, Sanal işbirliği, Bulanık ön uç.

JEL Sınıflandırması: M10, O32

"Corresponding Author, Bahçeşehir University, Architecht Bilişim Sistemleri - E-mail: senay.demirel@bahcesehir.edu.tr -

ORCID ID: https://orcid.org/0000-0001-7362-5384

**Vakıfbank, VLAB R\&D Center - E-mail: suhaerdem.yabas@vakifbank.com.tr ORCID ID: https://orcid.org/0000-0001-9659-3821

*** Özyeğin University, Faculty of Aviation and Aeronautical Sciences - E-mail: caglar.ucler@ozyegin.edu.tr ORCID ID: https://orcid.org/0000-0003-4209-7915

${ }^{* \star \star \star}$ Vakıfbank, VLAB R\&D Center - E-mail: sait.sener@vakifbank.com.tr - ORCID ID: https://orcid.org/0000-0001-6005-9424

*****Vakıfbank, Deputy General Manager - E-mail: metin.zafer@vakifbank.com.tr ORCID ID: https://orcid.org/0000-0002-6508-6170

Article Received: 29.04.2021 Article Accepted: 04.07.2021 DOI: http://dx.doi.org/10.46520/bddkdergisi.986618 


\section{Introduction}

There are many different definitions used for the term 'innovation'. One of the simplest definition stands for 'initial introduction of an idea into a business' (Trommsdorf et al., 1987, p.6). Schumpeter describes innovation as a "process of industrial mutation, incessantly destroying the old one, incessantly creating a new one" (Śledzik, 2013). Innovation management is used for "development, introduction and, as the case may be, implementation and enforcement of technical and social-technical initiatives of the management of the business" (Trommsdorff and Schneider, 1990).

Free market conditions necessitate differentiation for the sustainability of the operation. There, added value has to be delivered, which is effectuated by innovation (Amit \& Zott, 2012). This competitive advantage can be delivered by new innovative products or services (Tidd \& Bessant, 2013), or by implementing process, market or organizational innovation (OECD, 2018).

Particularly service companies are under the pressure of the experience evoked procurement decisions that they have to reach out innovations by pursuing "radical, me-too and incremental innovations" (Oke, 2007). This is especially evident in the financial services market, which is even making use external stakeholders as FinTechs (Wonglimpiyarat, 2017) besides the internal innovation flow to achieve the desired technological innovation in banking (Parameswar et al., 2017).

There, the wide variety of possibilities necessitates the implementation of a balanced innovation portfolio utilizing strategic buckets (Chao et al., 2008). Otherwise, organizations might be trapped within existing solutions without focusing on new to the world concepts. Hence, successful companies in mature markets need to increase bold innovation beside incremental efforts (Cooper, 2011) by a systemized approach enabling context, climate, and the associated innovation environment.

This is achieved and sustained by innovation management, where of knowledge management is an essential metric. There, idea generation, knowledge repository and the flow of the information can and shall be enhanced and thus measured (Adams et al., 2006). The increase of the information flow and the diffusion of ideas requires extensive collaboration within the $\mathrm{Ba}$ (Nonaka et al., 2008), which is the shared context for knowledge creation and its continuous exchange (Ucler \& Kristensen, 2016). So, there are many mechanisms guiding the information flow based on mutual interactions. 
Nonetheless, there was a recent radical disruptor: The COVID-19 outbreak in late December 2019 spread out from Wuhan, China across the world, and it impacted the way of how the work is done. Many organizations rearranged their habits and started to implement flexible work hours and distant working, where virtual collaboration did emerge as a key requirement.

While the transformation of tacit into explicit knowledge is a challenge itself, the lack of physical transactions at the fuzzy front end of innovation further complicated the situation. Therefore, the existing system of the selection of potential innovation ideas is subject to be reviewed and updated. Thus, the flowing research question is crystallized:

R1. How can the ideation stage of an Innovation Management System for the Banking Sector be conceptualized in the lack of physical interactions in the pandemic situation?

The structure of this research paper is as following: First, (i) the status quo for innovation management in general and specifically in Finance Industry is reviewed. Then, (ii) distant collaboration issues are looked at to (iii) discuss the implementation of VakıfBank Innovation Management System (V-IMS) based on evidence collected during the action research.

\section{Literature and Background}

According to the OECD definition; any innovation in the company, in its organization or in environmental relations can be an improvement in service, product or processes, an organizational management method or a new marketing activity (Oslo Manual, 2006, p.50). In general manner, innovation management are the decisions about innovation and the development of innovation process (Hauschildt, 2004).

\subsection{Innovation Management System (IMS) and Idea Evaluation}

Systematic approach to innovation management takes several interrelated and interacting components or factors into account, which have to be addressed in an organization. ISO 560002 standard and TS 16555 define this systematic approach and provides guidance for the establishment, implementation, maintenance, and improvement of IMS within a similar scope as per approved management system methodologies (ISO 560002, 2019; CEN, 2013).

As shown in Figure 1, one of the main components of an IMS is the innovation processes itself. The innovation process is usually set on a backbone of tools for 
collaboration utilizing information technology systems (Adamides and Karacapilidis, 2006), which also facilitate and increase the exchange of ideas through shared workspaces (Christensen et al., 2003; Sethi et al. 2003). Accordingly, systematic innovation flow can be achieved by IMS in a structured manner, targeting innovation inline with strategic perspectives of the organization (Karlsson, 2013). There, IMS is a total approach (Ucler and Yavuz, 2019) particularly fostering collaboration and integrating knowledge management and creativity development for new business creation (Mandić, 2014). Then, distinct systems are utilized for the execution of innovation idea development (Bose, 2003), and Group Decision Support Systems enable the processes of decision-making, negotiation and evaluation for the selection of these ideas within a collaborative environment.

Figure 1: ISO 560002 Guiding Standard for IMS. Source: (ISO, 2019)

\section{Innovation Management System}

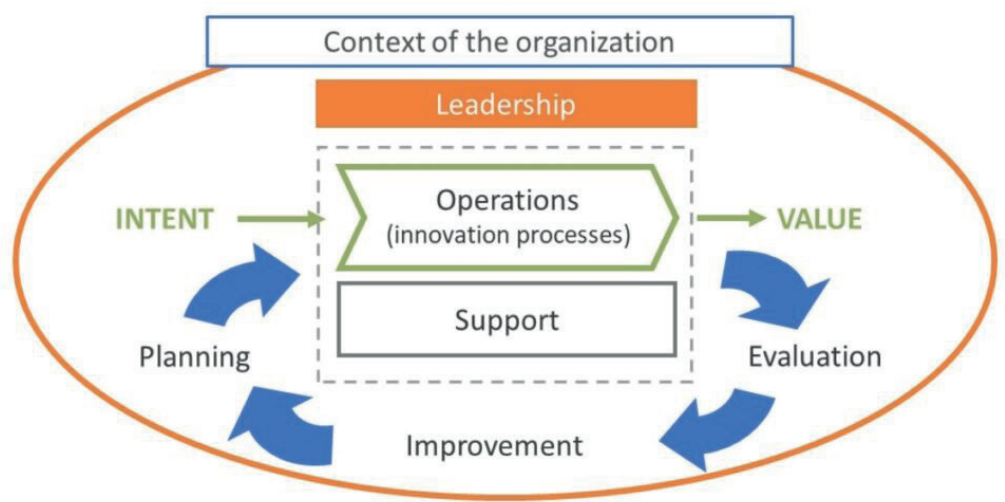

Based on the concept of the idea evaluation approaches, Hrastinski et al. (2010) investigated a range of selected idea evaluation products and underlined that existing commercial systems actually use fairly simple opinion assessment methods. Gorski and Heinekamp (2002) provided an illustrative example of how the indeterminate front end of the innovation process works as part of an overall idea management system. There are many studies like Alexandru Spatariu ve Bendixen (2004), Nisbet (2004) and Stromer-Galley (2007), who are attempting to analyze the characteristics of the content or discussions created by the communities in a collaborative manner. Dodgson (1993) and Hagedoorn (2002) emphasize the importance of Inter-organizational collaboration to supplement the intra-organizational collaborations. Also 
Collaborations with all stakeholders like existing suppliers and customers (Shaw, 1994), universities and research centres (Gerwin et al., 1992; Santoro, 2000; Tidd et al., 2002), potential lead users (Von Hippel et al., 1999) and potential or existing industry competitors (Dodgson, 1993) have all been advanced to support innovation ecosystems of the companies.

Börjesson et al. (2006) indicate that in all innovation methods, there is an evaluation/ idea selection task for organizing ideas as part of an IMS. Usually, stage gate mechanisms are used by IMS systems as a best-practice (Griffin, 1997; Cooper et al., 2000 \& 2005; Ucler and Yavuz, 2019). However, according to Bröring et al. (2006), each project is at the same time unique and requires a different approach for evaluation. Kurt et al. (2017) implied that there is no comprehensive but simple innovation idea evaluation method even if organized for fuzzy logic. Gangi and Wasko (2009) even go further and concluded that none of such methods available in practice may have a significant impact on which ideas are implemented by organizations. As a result, innovation management system and the idea selection within are subject to intrinsic organizational factors and extrinsic sector constraints.

\subsection{IMS in Finance}

There is few academic research evident specifically with IMS applications for the finance sector and banking. There are some scholarly works for innovation at financial institutions, which also contribute to the IMS in finance particularly by some of their content.

Parameswar et al. (2017) described the technology innovation initiatives of Industrial Credit and Investment Corporation of India Bank $(\mathrm{ICICI})$ and identified the challenges mainly as leadership, technology and impact of failed projects that the 4 P's of innovation by Tidd \& Bessant (2013) are proposed, i.e. product, process, paradigm as well position innovation are suggested to be applied simultaneously, which is also in line with the strategic bucket approach of Chao and Kavadias (2008).

Arnaboldi and Rossignoli (2015) proposed a measure for financial innovation, based on bank's annual reports, where they focused on six innovation categories, i.e. new (i) organizational models/ (ii) structures, (iii) operating systems, (iv) information and communication technologies (ICT), (v) delivery channels and (vi) products. Hence, impact factors were investigated concluding that younger banks with a larger market share tend to be more innovative, while such banks are more cost-efficient, but less profitable as well (Arnaboldi \& Rossignoli, 2015). 
Lyons et al. (2007) introduced a case study about innovation in Investment Banks, and focused on innovation in the banks as service companies; as they did identify the innovation as a continuous distributed process rather than discrete event, where strategic orientation has to be kept by organization foundations and leaderships over long periods of time.

Serinkan and Kızıloğlu (2015) tried to determine a relation between innovation management and teamwork based on Turkish Banking Sector. The data used in the model is collected from a survey with the personnel working at the banks in Denizli (a city in Turkey) province only. They found a significant positive relationship between innovation management and teamwork, and advice to support collaborative organizational climate that facilitates innovation management.

Consequently, all research indicates there is a need of joint efforts across the whole organization to assure the continuous innovation led towards strategic targets. Then, it is important to understand innovation ideas correctly especially at initial phases of the innovation process that the potential innovation value can be captured and even further enhanced by collaboration, which is discussed next with respect to the new normal.

\section{Distant Collaboration at Fuzzy Front End}

The term fuzzy Front End (fuzzy FE) refers to the early phase at the beginning of the ideation for the innovation. It is described fuzzy due to the uncertainties involved: both, the idea as well its real life applications are not formed yet, and they both evolve during the preliminary phases of the product development. Reid and Brentani (2004) denotes that the FE includes all the time spent on the idea generation, enrichment and strengthening it. FE's focus is on product/ service development and helps to result in competitive advantage according (Kim \& Willemon, 2002). It focuses mainly on identifying opportunities and analyzing context before the actual idea management (Belliveau et all, 2004; Khurana and Rosenthal, 2002). This stage is especially describing the formalization of the tacit knowledge in the form of ideas of employees towards explicit innovation proposals.

Execution of coordination, management and control on technological collaboration environment is a difficult concept (Becker \& Dietz 2004). While the collaboration during ideation is a challenge itself, the new normal of the pandemic environment further complicates this situation: due to the updated work policies of companies, physical meetings are being transformed towards virtual meetings and 
the information has to be carried over through different modes of communication.

While multinational corporations in the production sector already utilize intelligent knowledge sharing with collaborative technologies (Lima \& Carpinetti, 2011) for inter organizational mutual knowledge generation (Casanueva et al., 2013), this is particularly new to the banking environment, which has been more traditional with an established physically collocated work culture.

Virtual collaboration, together along with collaboration, refers to the use of ICT for supporting the collective interaction among multiple parties involved (Kock, 2000; Hossain \& Wigand, 2003). There, the usage of ICT enables an interactive virtual communication environment (Camarinha-Matos et al., 2008), which unfortunately lacks on management guidance (Westphal et al., 2008) and trust (Msanjila ve Afsarmanesh, 2008). Furthermore, the ICT infrastructure becomes a challenge itself due to the distributed nature of the participants.

When participants are at distinct spaces, their commitment performance is reduced (Ale Ebrahim et al., 2009) as well. This is partly based on the reduction of the communication channels available, i.e. the participants cannot utilize their body language. Then, different time zones can be lived in by participants or home office participators might have different adoptive work schedules. Hence the performance of the virtual interaction is a spatial, configurational and a temporal function (Lockwood et al., 2013).

Moreover, it is common that a blended interaction involving asynchronous channels is a common approach. This can involve different communication channels such as emails or reports. Then, while some of the members remain updated due to personal interactions, other members can remain disclosed. The quality of interaction might be dropped to a lower bound that the outcome of the collaboration, i.e. the ideation quality, can be reduced.

Then, the continuous circulation of the idea has to be enabled (Nonaka et al., 2008). There, employees have to communicate with each other several times to internalize the information and yet to generate new ideas based on it. This requires the appropriate environment corresponding to the Ba of Nonaka et al. (2008), which can be achieved by virtual means, where the shared context for knowledge generation can lead towards innovation (Ucler \& Kristensen, 2016).

All in one, challenges and thus requirements in distant collaboration at Fuzzy FE within the innovation process can be summarized as below: 
- sustainability of virtual collaboration with a suitable environment for continuous remote collaboration

- optimal use of ICT supporting geographically dispersed work groups with web based video conferencing with instantaneous feedbacks

- commitment of team members within an open communication without any prejudices

- collective information growth for the transformation of tacit into explicit knowledge

- virtual work culture building trustworthy relationships among the actors

Based on these requirements an innovation management model is conceptualized, which allows delocated collaboration under the 'New Normal' conditions of Banking.

\section{V-IMS}

V-IMS is the innovation management system of VakıfBank and managed by 'R\&D and Innovation Directorate. The fundamental goal of V-IMS is to collect as many innovative project ideas as possible which are subsequently evaluated and selected carefully. Expected benefits from V-IMS can be summarized as below:

Making improvements in business or resolving recurring problems with creative solutions

With new processes and procedures, increasing the productivity

Increasing effectivity by applying new ways of making business

Increasing the quality and showcase it with business values

Gaining advantage in competition by releasing innovative projects

Helping out with motivation in employees and thus in performance as a consequence

In idea management there are couple of key factors that V-IMS also focuses on to accelerate; collaboration, idea enrichment, fuzzy front end considerations, evaluation criteria along with the process and the business model for the evaluated ideas. 


\subsection{V-IMS Method}

Method applied in V-IMS in general is the action research method. Action research is a method of enquiry partly by incorporating the subjects into their research as powerful collaborators (Brem and Voit, 2007). It refers to the research where researchers are actively involved on the matter of concern (Eden \& Huxham, 1996). Consequently, action research always involves a team that includes researchers and subjects as co-participants in the enquiry and change experiences. It is situation based and context specific (Ucler and Yavuz, 2019). In this method action brings understanding and according to this understanding, collaborative change experiments are involved leading towards knowledge being formed on them.

On V-IMS side, innovation experts are both the researchers and actioners. They implement the innovation process, execute it, and according to their findings, V-IMS is being altered in order to improve the innovation effect in the organization. There are KPI s collected by the system to measure the effects. Sometimes, the effects were also being measured by performing surveys or feedbacks. Then, unstructured interviews with the participants of the ideation processes were made together along with observations to isolate also the satisfaction, commitment levels, preferences of the employees interacting with the outcome of the implementation of V-IMS. Consequently, hybrid data was used to evaluate the outputs of the system that improvement actions were taken into account for the further development of the system as well.

The time frame for this data is limited due to practicality issues: Only studies carried out within the VakıfBank R\&D and Innovation team between 2019-2020 were examined, since the past information is imperfect. Moreover, this work necessitated with the Covid outbreak, urging a disruptive switch from the old fashioned office work to the new virtual arrangement. However, since there was no virtuality involved in the past time, the isolated observation within this limited context is also considered to be acceptable for the generality. To gather continuous information over time, at least weekly meetings were held with the dedicated team. Then, idea evaluation meetings were organized once a month, and R\&D Board Meetings were held with the associated managers of VakıfBank. Within those meetings, Brainstorming and Delphi methods were used for proposing and further developing system changes. VakıfBank was considered to be a good case for this research, because being one of the largest banks in Turkey, it is showing up a wide spread across Turkey and having traditionalist banking origins together along with the commitment to

Ş. Demirel, S. E. Yabaş, Ç. Üçler, S. Şener, M. R. Zafer, “Idea Evaluation in Innovation Management for the New Normal in Banking: A Case Study in Vakıfbank", Journal of BRSA Banking and Financial Markets, 15, (1), 2021, 1-26 
innovate, the transformation is particularly of interest. There, the existing innovation organization of VakıfBank also delivered the required environment to interact, the tools and the freedom to operate that the selection of this case was solidified from pragmatic perspective as well.

\subsection{VakıfBank Innovation Management System (V-IMS)}

\subsubsection{Idea Funnel}

V-IMS utilizes the Stage-Gate Model of Cooper (1990) as a basis for ideation. There, sole innovation ideas with limited application information are collected among the stakeholders, which are then further detailed after a first elimination. The structure of the idea funnel used in V-IMS is shown in Figure 2.

Figure 2: The Idea Funnel in V-IMS. Source: own conceptualization based on (Cooper 1990)

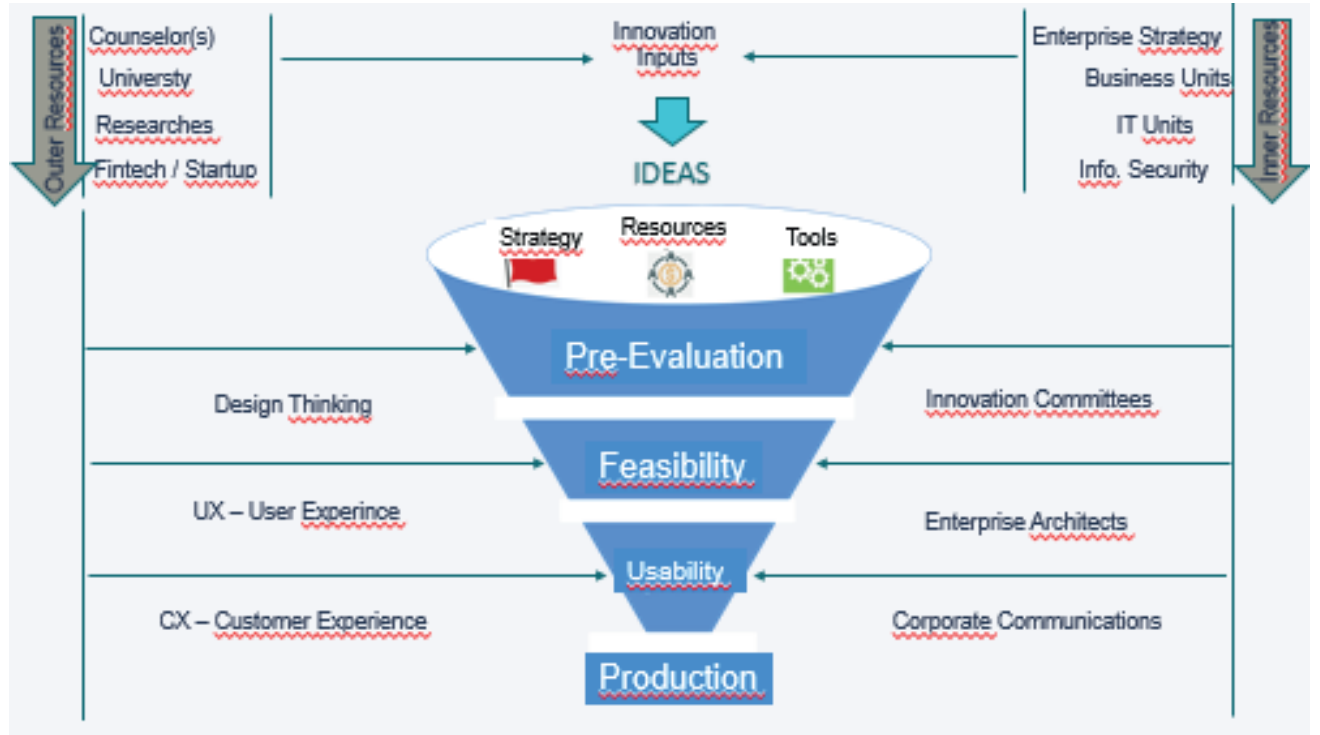

There are different stakeholders in the idea tunnel which can be grouped into two category: outer and inner resources. Outer resources include universities, researcher organizations, fintech/startups and counselors whereas inner resources include corporate strategy, business units, IT units and information security. It is actually can be any stakeholder - whether not specified here - which has an interaction with the company and has an idea that is relevant.

On the left side, the ideas are trying to be strengthen by using different methods like design thinking workshops, user experience (UX) or customer experience (CX) 
designs. In the middle, main stage gates are shown and on the right side the key stakeholders are specified. In the evaluation phase, there are two different committees that evaluate the ideas by voting and ordering them. In the feasibility phase architects also involved in the project and best architecture and design is trying to be specified. And in pre-usage experience phase CX design is either demonstrated to the business units or POC work is completed with them within the product development cycle. In all steps, the idea is to gain strength with collaboration and the effects of it is to have a broader perspective as different parties are involved in the journey of the idea.

\subsubsection{Idea Evaluation Criteria and Weights}

One of the important steps in IMS is the evaluation of project ideas and so setting up the correct criteria set for your company according to your goals and strategy. Major decisions have to be made in order to specify the criteria set as well as the weights of each criteria as that can change the project scores, orders and so the winners. V-IMS have adopted evaluation criteria at decision gates to offer the decision makers' sufficient knowledge of the alternative ideas and concepts, and to promote choices that would result in the best possible business benefit.

In the implementation phase of V-IMS, evaluation criteria are associated with innovation performance in the front end of innovation and criteria set built up with some academic research, with the insights of research companies (such as Gartner, Forrester) and with executive level preference. The weights of the criteria are determined by applying one of the most common method of multi-criteria decision making, Analytic Hierarchy Process (AHP) of Saaty (1990). Since AHP in conjunction with ideation is widely studied in the literature (Ucler, 2018), it will not be detailed in this paper.

Main criteria set and its properties are described in Table 1, below. 
Table 1: Criteria Set and Weights

\begin{tabular}{|c|c|c|c|}
\hline Criteria & Score & Definition & Weight \\
\hline Align with company strategy & Yes or No & $\begin{array}{l}\text { It is an } 0 \text { or } 1 \text { gate whether you can drop to idea } \\
\text { if it is not aligned with the company strategy } \\
\text { or not. }\end{array}$ & $(0,1)$ \\
\hline Return investment time & 1 to 5 & $\begin{array}{l}\text { Estimated turnover value/time for the project. } \\
\text { It is a minimization criteria as shorter turnovers } \\
\text { are preferred. }\end{array}$ & $\% 10$ \\
\hline Resource Requirement (Cost) & 1 to 5 & $\begin{array}{l}\text { Estimated cost of resource (resource by } \\
\text { means of people, technology, knowhow or } \\
\text { any resource required for the project). It is a } \\
\text { minimization criteria as lower resources are } \\
\text { preferred. }\end{array}$ & $\% 10$ \\
\hline Execution Risk & 1 to 5 & $\begin{array}{l}\text { Execution risk of the project, whether it has } \\
\text { dependence to a outsource factor or effecting } \\
\text { the whole organization, a specific group, } \\
\text { department or so. It is a minimization criteria as } \\
\text { lower risk is preferred. }\end{array}$ & $\% 10$ \\
\hline Benefit for the Bank & 1 to 5 & $\begin{array}{l}\text { Any benefit for the bank, decrease of costs, } \\
\text { increase of incomes etc. It is a maximization } \\
\text { criteria as higher benefit is preferred. }\end{array}$ & $\% 15$ \\
\hline Benefit for the Customer & 1 to 5 & $\begin{array}{l}\text { Any benefit for the customer, increase in } \\
\text { customer pleasure, new customer potential } \\
\text { or increase in customer loyalty etc. It is a } \\
\text { maximization criteria as higher benefit is } \\
\text { preferred. }\end{array}$ & $\% 30$ \\
\hline Impact to the Risk Items & 1 to 5 & $\begin{array}{l}\text { Any impact to lower the current risks of the } \\
\text { bank. Such as decreasing a regulation risk, an } \\
\text { operational risk, financial or a reputational risk. } \\
\text { It is a maximization criteria as higher impact to } \\
\text { decrease the risk is preferred. }\end{array}$ & $\% 10$ \\
\hline R\&D score & 1 to 5 & $\begin{array}{l}\text { R\&D potential of the project to help the KPI's } \\
\text { of R\&D Center of the bank. }\end{array}$ & $\% 15$ \\
\hline
\end{tabular}

* Source: (VakıfBank, 2020)

\subsubsection{Expert Views and MCDM (Multi Criteria Decision Making)}

The preliminary assessment of the ideas is done by the innovation experts according to above criteria set. The innovation experts are also the action researchers as highlighted before and they have different backgrounds either from technology and finance domains.

The preliminary assessment is performed by applying the Multi Criteria Decision Making (MCDM) methods such as Weighted Sum Model, WSM, or Weighted Product Model, WPM) after each expert is evaluating a specific idea according to his/ her judgements. The MCDM methods help to deal with the fuzzy front end of the ideas and making a collaborative multi criteria, multi expert judgement in order to find the best matches. 


\subsubsection{Stage Gates and Innovation Committees}

Expert views are actually the first stage gate and helps to decrease the number of project ideas that will go on with the IMS life cycle. There is a threshold value defined which eliminates the ideas if their score cannot pass the threshold. The project ideas are in PROPOSED status before they are presented to any committees.

There are two main committees and thus two other stage gates in V-IMS infrastructure.

\section{1- Innovation Execution Committee:}

The idea owners represent their ideas with a predefined project proposal form (namely POF) and the committee members are is responsible of evaluation of the projects. Committee members are selected from different departments and are in the manager position mainly.

The committee can decide either in 3 ways. They can ask for a POC work if there are some points which are not clear, includes a new technology that is not applied even before in the company or there are some concerns for the applicability of the idea in general. If that happens, idea status will be POC state.

If committee is ok with the idea and wants to go on with next level, then status will be EVALUATED. If the idea cannot pass the evaluation step, it will be moved to DROP status. Of course, this may happen in any of the stage gates during evaluation.

\section{2- Innovation Management Committee:}

This is the executive level of the innovation and official approval of the pre-evaluated ideas are given by this committee.

If the committee approves the idea, it means they are sponsoring the project so banks' ongoing project process needs to be started by opening up the official demand for the project. The idea then will move to DEMAND status and it will be started to be tracked as an Official Project. Innovation projects has higher importance than regular ones and are executed in a separate queue than others. The overall lifecycle of an innovation idea is illustrated as below with stage gates, in Figure 3. 


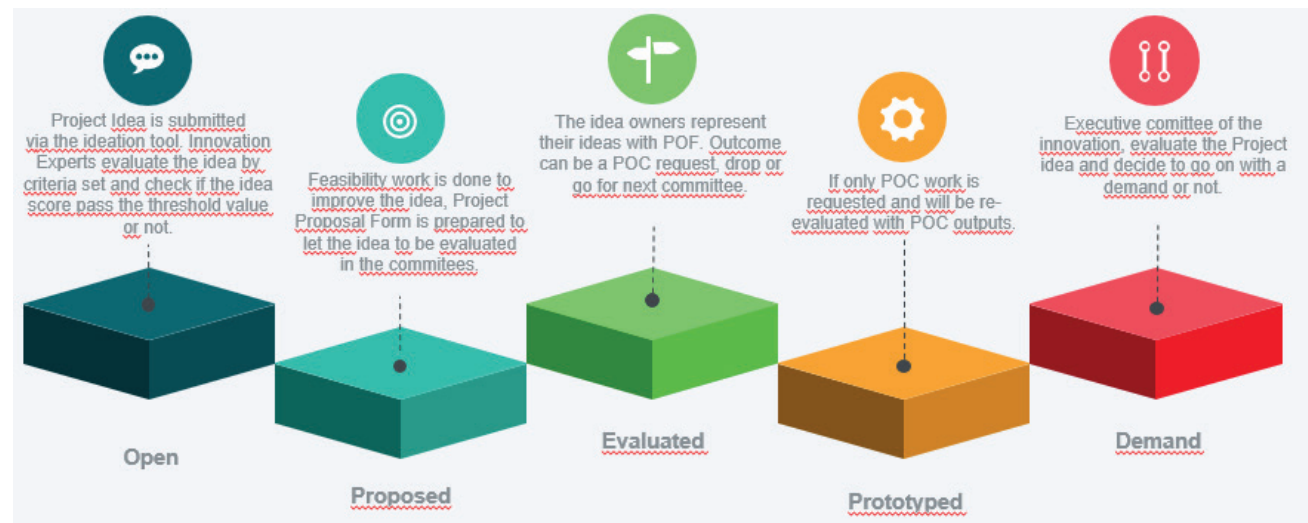

\subsection{V-IMS Improvements - Fuzzy Front End, Delocated Collabora- tion and the new Normal}

As similar to many industries, because of the pandemic effect, working model of the bank is moved to home office as much as possible. So physical meetings of innovation process are transformed towards virtual meetings with optimal use of ICT supporting geographically dispersed work groups with web based video conferencing. ICT is the key in sustainability of virtual collaboration with a suitable environment for continuous remote collaboration.

Video conferencing helps to prevent some of the members of the committee members remain disclosed as even it is possible to carry out the information over through different channels (such as email or reports), video conferencing let any party to be updated with the latest info and situation. Disclosure may partly be based on the reduction of the communication channels available, i.e. the participants cannot utilize their body language. Video conferencing helps to facilitate limited face to face interactions and to provide instantaneous feedbacks. Thus, improving the quality of the collective interaction helps to sustain the ideation quality.

Also, shorter and focused conferencing sessions are trying to be arranged to increase the commitment performance of the participants. The focus is kept on collective information growth for the transformation of tacit into explicit knowledge in a shorter period. That requires commitment of participants within an open and direct communication without any prejudices and building the virtual work culture trustworthy relationships among the parties. 
V-IMS is built on the pre-acceptance of the fact that both the idea as well as its real life applications are not formed yet, and they both evolve during the preliminary phases of the idea and product development. During the expert views - the very first stage gate - feasibility actions are taken to improve the idea content, to determine its business model and to reduce the uncertainties in the content of idea. Idea owners find opportunity to work closely with the innovation experts, as they are their mentors, and form up the idea into a structured way and built up the project proposal forms (namely POF).

POFs provide the intelligent knowledge sharing with collaborative information. During the pandemic, based on the action research method, there are some improvements made in forms in a way that focus more on the critical data instead of drowning in the details (transition from POF 1.0 to POF 2.0). For the idea owners, that allows to describe the idea in a more basic, shorter and effective way which needs to become a real expert on the idea as it is always harder to describe it simply. Also for the stakeholders that helps to focus on a shorter periods during the virtual collaboration and concentrate more on the actual points.

Evaluation is another challenge as there are difficulties in fully understanding the idea owner, different approaches/backgrounds of the evaluators, uncertainties in the content of the idea, missing or weak data and such. To face the challenge, the weights of the criteria's and the preliminary assessment is performed by applying the MCDM methods to help to deal with the fuzzy front end of the ideas and making a collaborative multi criteria, multi expert judgement in order to find the best matches.

The newest initiative is to alter V-IMS to function more as an open innovation platform. Open innovation actions started up with the meetup sessions which are now held online because of the pandemic. With meetup sessions, people from outside world are invited to have some short speeches to the organization. That allows different speakers to share their knowledge, experience or lessons learned through short talks and presentations with the goal of informing, educating, motivating or inspiring the employees and help to support innovative culture. Design thinking workshops are also being held to help them the increase their awareness and find a way of innovative thinking.

Demoday's with Fintech companies are arranged to show employees what kind of features are being presented to the financial market by Fintechs. That allows them to learn the latest improvements and help to understand what kind of cooperation's are potential with them.

Ş. Demirel, S. E. Yabaş, Ç. Üçler, S. Şener, M. R. Zafer, “Idea Evaluation in Innovation Management for the New Normal in Banking: A Case Study in Vakıfbank", Journal of BRSA Banking and Financial Markets, 15, (1), 2021, 1-26 
Similarly, as an open innovation action, hackathons are started especially with the focus of collecting ideas from younger generations. It is also held as an online event and selected ideas are widely announced and rewarded by the bank.

And the latest initiative is to alter V-IMS in a way that allow some social interactions. That will allow wide range of other people to see the idea and to show their reactions such as liking the idea, or commenting in the idea. That will help to collect ideas from social media directly as well as help evaluators to see the direct reactions instantly from outside world and help to decrease the fuzziness.

\subsection{Results and Discussion}

There are couple of benefits observed after the improvements. First of all, the committee sessions began to start just on time in an agile manner without having much delays while waiting for all members to join. Delays occurred from waiting all attendees to be physically in the meetings have been eliminated. Consequently, a suitable environment was provided for concurrency by means of virtual tools delivering the Ba of Nonaka et al. (2008), which is capable to integrate geographical spread of the work force.

Then, the ideas are presented in shorter times with POF's being improved in POF 2.0 version, which is by far much simpler and easier to fill in. For the idea owners, they describe their ideas in a simplistic view focusing on the added value. This enables a shorter and effective way for communication and the lean formulation eases the interaction of the stakeholders. It is also observed that evaluation process takes shorter time and voting becomes smoother. Furthermore, transformation towards explicit knowledge is enhanced by the new POF, since it simply increased team efficiency that more time can be spend on collective development of ideas.

Committee members have the ability to evaluate the ideas with online tools which helps them to provide free judgements for independent voting. On the one hand, this helps to decrease the effect of peer pressure. Online voting also provides ability to the stakeholders to vote later for the ones who couldn't attend the sessions. On the other hand, this provides a transparent structure contributing to the trust environment further increasing the open communication between stakeholders.

For the idea owners, who could not attend the meetings physically, online sessions helped to extend the participant profiles. Meaning that, employees from different branches or cities started to present their ideas smoothly in the online 
sessions. Earlier, innovation experts were their first contacts, who get the idea details and make their presentations on behalf of the idea owners. In this new form, idea owners find the opportunity to work closely with the innovation experts, as their mentors, and form up their ideas into a more structured way, which they can present in their own pitch sessions. This participation delivers a high perception of ownership for both ends; the committee members can see the commitment behind the ideas and the idea owners are included in the process that their organizational citizenship is accentuated. In addition, idea owners have also been motivated by having the chance of interacting with the upper management, which was observed during the interviews with the participants contributing to the innovation process. That also decreases the fuzziness of the overall process and evaluators have chance to ask to the idea owners, by getting in touch directly.

As a result, the sessions are held in more participative environment, encouraging people and letting feedbacks directly. The process itself is accelerated and both the number of sessions and ideas presented in the sessions have increased significantly, where the tacit knowledge was captured and transformed into explicit knowledge on the move.

More importantly, the culture of innovation has been created from scratch and its effects are increasing in the bank. This transformation is realizable in the outside world as well and being supported with different activities, as summarized in Table 2, below.

Table 2: Innovation Activities

\begin{tabular}{|l|l|}
\hline \multicolumn{1}{|c|}{ Innovation Action } & \multicolumn{1}{c|}{$\mathbf{2 0 1 9 - 2 0 2 0}$} \\
\hline \multirow{2}{*}{ Meetups } & $\begin{array}{l}\text { 20 meetup sessions, more than 2000 participants, } \\
\text { different topics (such as Open Banking, RPA, PSD2, Big } \\
\text { Data, CX Design, Attention Economy or Personal Finance } \\
\text { Management) }\end{array}$ \\
\hline Design Thinking Workshops & 7 design thinking workshops, over 160 participants \\
\hline Demo Days & 54 Fintechs, held their pitch sessions \\
\hline Ideation & More than 250 ideas (evaluated in the process) \\
\hline POCs & $\begin{array}{l}\text { More than 15 POC projects, } \\
\text { (completed with successful results and go to production) }\end{array}$ \\
\hline
\end{tabular}

* Results based on measurements made by VakıfBank R\&D and Innovation Management Team subject to full coverage within Turkey. 
VakıfBank has become the first public bank in Turkey that organizes a hackathon. In first year, teams applied from 71 different universities, and 120 project ideas are submitted to the system. The second 'Hack to the Future' event has finished recently on March 19-21, 2021. 'Best Minimum Viable Product', 'Best Social Enterprise', 'Most Innovative Technological Solution', 'Best User Experience Design' and "Most Global Solution" categories met with their owners and awarded.

The projects implemented as a result of V-IMS innovation ideas has started to be evaluated in different competitions. The bank has received awards from different competitions such as:

- PSM Awards 2020: Dijital Transformation, Innovative Customer Interaction \& Experience Categories

- IDC Awards 2020: Omni Experience Innovator and Stevie Mena (Middle East North Africa) Awards 2020, Innovation in Technology Development, Gold Awards and

- IDC CIO Awards : Special Award recently.

These results are shared with employees by publishing innovation bulletins yearly. Also employees are being awarded by the company with incentive regulation of the bank itself.

The added value of this new methodology is also looked at. Since, the pandemic was a disruptive event without a transition phase, there were no metrics to compare with historic data, i.e. the method applied created a new way of working which was not possible before. Furthermore, this new approach is expected to change the way of working and thus to impact heavily in the future. Consequently, there is an analogy to IT innovation, which cannot be measured directly with traditional measuring techniques (Granta, et al., 2013) as well. This means that the added value can be measured only qualitatively. There, a qualitative assessment leaned on Porter's (1998) value chain analysis is utilized with the focus on support activities, which the V-IMS is embodying as well: First of all, V-IMS has provided an infrastructure enabling the ideation and the selection of evolved ideas at the front end. This was not possible on virtual basis before the pandemic at all. Then, it contributed via the virtual collaboration aspects embedded to the interaction of employees, which added to the human resources management. This was also totally new to the organization, because pre pandemic work culture was based on physical presence. The new virtual meetings with simple representation of ideas accelerated the process of the 
ideas. Consequently, agile new technology development was enabled leveraging a high number of innovation projects. All in one, all support activities of Porter (1998) except procurement were enhanced delivering a solid added value. This aspect is expected to be included within future work when the open innovation chapter is implemented as well, which is an ongoing work.

\section{Conclusion}

The work landscape is disrupted by the new normal set by the COVID-19 outbreak. Companies became flexible with regard to physical workspaces. This resulted in many issues related to the collaboration based processes. Particularly innovation management was impacted due to its nature build on collaboration and fuzzy content.

There, the way of its execution is radically changed towards virtual. However, there are many effects of virtual collaboration required by delocation especially due to the fuzziness and collective information generation. As a result, V-IMS is exemplified as an ongoing actual innovation management model, which is suitable to be used in the new normal. It consists of real life system experience discussed here successfully based on the action research method.

Although pandemic effects expected to be in shorter terms, it generated a radical shift of the mindset that many changes introduced in the way of business can become permanent. Consequently, banking environment, which is known to be traditional with an established physically collocated work culture can transform adequately to suit the new normal. The real life outputs are provided to show how traditional banking environment is transforming to an open innovation platform. Also the supporting actions of this innovation transformation is provided in the Results section with numerical metrics in order to share the real outputs. So, the proposed model of this paper has a managerial impact, and it is contributing to the literature by introducing a real life innovation management model with its all components (including the stage gates, the evaluation criteria sets) and discussion of the virtual collaboration within the fuzzy front end of the ideation process is provided to help the describe the COVID 19 effect.

This paper is based on action research in banking and future research can be done by including further financial institutions or other domains. However, the generality is assumed to be provided due to the special consideration that large banks have similar patterns due to the high regulations. Further research can be done by

Ş. Demirel, S. E. Yabaş, Ç. Üçler, S. Şener, M. R. Zafer, “Idea Evaluation in Innovation Management for the New Normal in Banking: A Case Study in Vakıfbank", Journal of BRSA Banking and Financial Markets, 15, (1), 2021, 1-26 
using online automated tools or software that has its own scoring which encourages and having auto reminders for idea evaluators. Also collecting community responses (likes, dislikes or comments) in an open innovation environment would also be useful for the idea evaluation. Innovation metrics can be compared yearly, after the pandemic resolved, in further researches as well.

\section{Acknowledgement}

Thank you Vakıfbank for enabling this research. 


\section{References}

1. Adams, R., Bessant, J., \& Phelps, R. (2006). Innovation management measurement: A review. International journal of management reviews, 8(1), 21 47.

2. Adamides, E. D., Karacapilidis, N. (2006) "Information Technology Support for the Knowledge and Social Processes of Innovation Management", Technovation, vol. 26, pp. 50-59.

3. Ale Ebrahim, N., Ahmed, S. \& Taha, Z. (2009), “Virtual teams: a literature review," Australian Journal of Basic and Applied Sciences, 3(3), pp. 2653-2669.

4. Alexandru Spatariu, K.H., Bendixen, L. D., (2004). "Defining and measuring quality in online discussions Journal of Interactive Online Learning 2 (4).

5. Amit R. \& Zott C. (2012), "Creating value through business model innovation", MIT Sloan Management Review, 53(3), 41-49.

6. Arnaboldi F., Rossignoli B., (2015) "Bank risk, governance and regulation", Springer

7. Belliveau P., Griffin A and Somermeyer, S.M. (2004) The PDMA Toolbook for New Product Develeopment, Hoboken: John Wiley \& Sons.

8. Bose, R.(2003), "Group support systems: technologies and products selection", Industrial Management and Data Systems, vol. 103, no. 9, pp. 649656.

9. Börjesson, S., Dahlsten, F., and Williander, M. (2006), "Innovative scanning experiences from an idea generation project at Volvo Cars", Technovation, 26(7), 775- 783 .

10. Brem A. and Voigt K. (2007) 'Innovation Management in Emerging Technology Ventures - the concept of an integrated idea management', Int. J. Technology, Policy and Management, Vol 7. No 3. 2007

11. Bröring, S., Cloutier, L.M., and Leker, J. (2006), "The front end of innovation in an era of industry convergence: evidence from nutraceuticals and functional foods", R\&D Management, 36(5), 487-498. 
12. Camarinha-Matos, L.M., Afsarmanesh, H. \& Ollus, M. (2008), "ECOLEAD and CNO base concepts," in Methods and tools for collaborative networked organizations, pp. 3-32. Springer, US.

13. Casanueva, C., Castro, I. and Galán, J.L. (2013), "Informational networks and innovation in mature industrial clusters," Journal of Business Research, 66(5), pp. 603-613.

14. Chao, R.O. and Kavadias, S. (2008), "A theoretical framework for managing the new product development portfolio: When and how to use strategic buckets", Management Science, 54(5), 907-921.

15. Christensen, C., Magnusson, M.G., Zetherstrom, M.B. (2003), "Implementation and Use of Collaborative Product Development Systems-Observations from Swedish Manufacturing Firms", Department of Innovation Engineering and Management, Chalmers University of Technology, Working Paper 2003:1, Sweden.

16. CEN (2013), "CEN/TC 389 - Innovation Management /TS 16555," Technical Specification, European Committee for Standardization.

17. Cooper R.G. (1990), "Stage-Gate Systems: A New Tools for Managing New Products," Business Horizons, 33(3), pp. 44-54.

18. Cooper, R.G. (2011), "Perspective: The innovation dilemma: how to innovate when the market is mature", Journal of Product Innovation Management, 28(s1), 2-27.

19. Cooper, R.G., Edgett, S.J. and Kleinschmidt, E.J. (2002). New Product Development Best Practices Study: What Distinguishes the Top Performers. Houston: APQC(American Productivity \& Quality Center).

20. Cooper, R.G., Edgett, S.J. and Kleinschmidt, E.J. (2005). Benchmarking Best NPD Practices-3: The NPD Process \& Key Idea-to-Launch Activities. Research-Technology Management ( 47)6: 43-55.

21. Dodgson, M. (1993) Technological collaboration in industry: strategy, policy and internationalization in innovation. London: Routledge

22. Eden, C., Huxman, C. 1996. "Action research for management research" British Journal of Management, 7:75-86. 
23. Gangi, P. M. D., Wasko, M., (2009). Steal my idea! organizational adoption of user innovations from a user innovation community: A case study of dell ideastorm. Decision Support Systems 48, 303- 312.

24. Gerwin, D., Kumar, V. \& Pal, S. (1992) Transfer of advanced manufacturing technology from Canadian universities to industry. Technology Transfer, Spring-Summer, 12: 57-67.

25. Gorski, C and Heinekamp, E.J. (2002) 'Capturing Employee Ideas for New Products'. In P. Beliveau, A. Griffin and S. Somermeyer (eds.), The PDMA Toolbook for New Product Dev. John Wiley \& Sons.

26. Granta, K., Alefantos, T., Meyer, M. \& Edgar D., (2013) "Capturing and measuring technology based service innovation - A case analysis within theory and practice". International Journal of Information Management, 33, pp. 899- 905.

27. Hagedoorn, J. (2002) Inter-firm R\&D partnerships: an overview of major trends and patterns since 1960. Research Policy, 31: 477-492.

28. Hrastinski, S., Kviselius, N. Z., Edenius, M., (2010). A review of technologies for open innovaton: Characteristics and future trends. In: Proceedings of the 43rd Hawaii International Conference on System Sceiences.

29. Hossain, L., and Wigand, R. T. (2003). Understanding virtual collaboration through structuration. Proceedings of the 4th European Conference on Knowledge Management, 475-484.

30. ISO (2019), "56002 Innovation management system - Guidance," https:// innovationmanagementsystem.com/portfolio-items/iso-56002-innovation-management-system-guidance/

31. Griffin, A. (1997). Drivers of NPD Success: The 1997 PDMA Report. Chicago: Product Development \& Management Association.

32. Karlsson, M. (2013). Who needs a standard for innovation management? Towards a management system standard (MSS) for innovation. Helsinki, Germany: XXIV ISPIM (International Society for Professional Innovation Management) Conference.

33. Khurana A. and Rosenthal S.R (2002) 'Integrating the fuzzy front end of 
new product development', in E.B. Roberts(Ed.) Innovation - Driving Product Process and Market Change, Cambridge: Jossey-Bass.

34. Kim,J and Wilemon D. (2002) 'Focusing the fuzzy front-end in new product development', R\&D Management Vol.32, No:4, pp 269-279

35. Kock, N. (2000). Benefits for virtual organizations from distributed groups. Communications of the ACM, 43 (11), 107-112.

36. Lima R.H.P. and Carpinetti, L.C.R. (2011), "Local Governance in Industrial Clusters: Proposal of a Management Model and a Self-Assessment Tool," in Proceedings of ITMC 2011, IEEE International Technology Management Conference, San Jose, CA, 2011, pp. 284-289.

37. Lockwood NS., Montoya MM., Massey AP., (2013) "Virtual Teams in New Product Development: Characteristics and Challenges" The PDMA handbook of New Product Development, Wiley Online Library

38. Lyons, R.K., Chatman, J.A., Joyce, C.K. (2007). "Innovation in services: corporate culture and investment banking", California Management Review, 50(1), 174-191.

39. Mandić, V. 2014. Methodology for innovation management. WBCInno project, EU Tempus Programme. Kragujevac, Serbia: Inter Print, University of Kragujevac.

40. Msanjila, S.S. \& Afsarmanesh, H. (2008), "Inter-organizational trust in VBEs," in Methods and tools for collaborative networked organizations (pp. 91118). Springer US.

41. Nisbet, D., (2004). "Measuring the quantity and quality of online discussion group interaction". Journal of eLiteracy 1

42. Nonaka I., Toyama R., and Hirata T., "Managing Flow: A Process Theory of the Knowledge-Based Firm. Palgrave Macmillan", 2008, New York.

43. OECD Publishing. (2018). Oslo Manual 2018: "Guidelines for collecting, reporting and using data on innovation". Organisation for Economic Co-operation and Development OECD.

44. Oslo, M. (2006). "The measurement of scientific and technological activities." Proposed Guidelines for Collecting and Interpreting Technological Inno- 
vation Data. European Commission and Eurostat-Manual de Oslo-Diretrizes Para Coleta E İnterpretação De Dados Sobre İnovação. Traduzido pela FINEP.

45. Oke, A. (2007). I"nnovation types and innovation management practices in service companies". International Journal of Operations \& Production Management.

46. Porter, M.E., (1998b) "Competitive Advantage: Creating and Sustaining Superior Performance, with a new Introduction". The Free Press.

47. Parameswar, N., Dhir, S., \& Dhir, S. (2017). "Banking on innovation, innovation in banking at $\mathrm{ICICl}$ bank. Global Business and Organizational Excellence, 36(2), 6-16.

48. Reid, S.E and de Brentani, U. (2004) 'The fuzzy front end of new product development for discontinuous innovations: a theoretical model', Journal of Product Innovation Management Vol 21, pp 170-184

49. Saaty, T.L. (1990), "How to make a decision: the analytic hierarchy process", European Journal of Operations Research, 48(1), 9-26.

50. Saaty Santoro, M. D. (2000) "Success breeds success: the linkage between relationship intensity and tangible outcomes in industry-university collaborative ventures. The Journal of High Technology Management Research, 11 (2): 255-273.

51. Serinkan C., Kızıloğlu M. (2015), "Journal of Management Policies and Practices", June 2015, Vol. 3, No. 1, pp. 94-102

52. Sethi, R., Pant, S., Sethi, A.(2003), "Web-based product development systems integration and new product outcomes: a conceptual framework", J. of Product Innovation Management, vol. 20, pp. 37-56.

53. Shaw, B. (1994) "User/Supplier links and innovation. In: Dodgson, M. \& Rothwell, R.The handbook of industrial innovation. Brookfield: Edward Elgar

54. Stromer-Galley, J., (2007). "Measuring deliberation's content: a coding scheme. Journal of Public Deliberation 3 (1).

55. Śledzik, (2013) "Schumpeter's View on Innovation and Entrepreneurship", SSRN Electronic Journal 
56. Tidd, J.; Bessant, J. \& Pavitt, K. (2002) "Learning through alliances. In: Henry, J. \&Mayle, D. Managing Innovation and Change. Second edition. London: SAGE.

57. Tidd, J. \& Bessant, J. (2013). "Integrating Technological, Market and Organizational Change, 5th Edition. Wiley.

58. Trommsdorff, V., Brodde, D. and Schneider, P. (1987) 'Modellversuch Innovations-management für kleine und mittlere Betriebe', Diskussionspapier 114, Berlin: Technische Universität- Wirtschaftswissenschaftliche Dokumentation.

59. Trommsdorff, V. and Schneider, P. (1990) "Grundzüge des betrieblichen Innovations-managements. Innovationsmanagement in kleinen und mittleren Unternehmen, in V. Trommsdorff (Ed.) München: Vahlen, pp.1-25.

60. Ucler, C., \& Kristensen, K. (2016, June). "CONTEXT: A Novel Approach for Collaborative Virtual Product Realization and Its Disclosure Using the Business Model Canvas". In 2016 International Conference on Engineering, Technology and Innovation/IEEE International Technology Management Conference (ICE/ITMC) (pp. 1-8). IEEE.

61. Ucler, C. (2018). Portfolio management for innovation ideas: weighing antecedents with AHP. Journal of Entrepreneurship and Innovation Management - JEIM, 7(1), 25-52.

62. Ucler, C. \& Yavuz, R.I. (2019), "Implementation of Innovation Management Systems in Large Companies of Different Typologies." Journal of business Research-Turk, 11(1), 189-201.

63. VakıfBank, (2020). Internal Procedure for Project Idea Evaluation, VakıfBank R\&D and Innovation Center. İstanbul.

64. Von Hippel, E.; Thomke, S. \& Sonnack, M. (1999)" Creating breakthroughs at 3M. Harvard Business Review", September-October: 47-57

65. Westphal, I., Mulder, W. \& Seifert, M. (2008), "Supervision of collaborative processes in VOs," in Methods and Tools for Collaborative Networked Organizations (pp. 239-256). Springer US.

66. Wonglimpiyarat, J. (2017) "FinTech banking industry: a systemic approach". Foresight, 19(6), 590-603. 